\title{
WOMEN EMPOWERMENT THROUGH PANCHAYATI RAJ INSTITUTIONS IN EAST SIANG DISTRICT OF ARUNACHAL PRADESH
}

KEY WORDS: Panchayati raj

institutions, women empowerment, rural development.

\section{Minbi Kaye}

Assistant Professor, Binni Yanga Government Women's College, Lekhi, Naharlagun, Papumpare, Arunachal Pradesh-791110.

The introduction of Panchayati Raj Institution in 1969 in the then, North East Frontier Agency (NEFA) and present Arunachal Pradesh brought landmark changes in the outlook of tribal society especially towards its women. The introduction of modern democratic institutions in grassroots level legally empowered the tribal women to participate in the decision-making process of the society. This was further boosted by $73^{\text {rd }}$ Constitutional Amendment Act, 1992 that reserved thirty three percent of the seats in Panchayat Institutions for the women. This really helped and empowered the women. Accordingly women are also elected as the member of PRIs. But it is often found that the rural tribal women lack in decision-making in various aspects whether it is social, economic, political or family matters and hence are dictated by their male counterparts.

\section{INTRODUCTION}

In India the concept of local self government was first introduced under the Government of India Act of 1919 and 1935 with minimal autonomy granted to the provinces. In 1950, when the Constitution of India came into force, the introduction and promotion of the institution of local selfgovernment was incorporated in the Directive Principles of the constitution. However, till the Balwant Rai Mehta Committee appointed in 1957, not much was done by the states in this direction. Hence, the National Development Council suggested to review the implementation of the Community Development Programmes and National Extension Service, and recommended for setting up of three tier system of rural local self government to be named as Panchayat Raj as an instrument of democratic decentralization through mass mobilization of community development programmes. As a result, now in almost all the states and union territories of India have local self government in the form of Panchayat Raj Institutions or in another form.

In 1950, Community Development programme was launched in Arunachal Pradesh with setting up of the first Extension Block in 1952. However, it was not until 1969 that the first Panchayat Raj was ushered in the state as it is in the rest of the country with similar structure and aimed at democratic decentralization of power. But the main objective behind the introducing Panchayat Raj in the state was to integrate it with the rest of the country by establishing a uniform political practice and an integrated political system throughout the state Arunachal Pradesh, the then NEFA. In May, 1989, the Government of India introduced the $64^{\text {th }}$ Amendment Bill which sought to reinvigorate and streamline the Panchayati Raj institutions. It sought to provide wide powers and more finances to the Panchayats. But the bill could not be passed due to the dissolution of Lok Sabha. The Congress I Government under P.V. Narashimha Rao, in keeping with the electoral commitment, re-introduced the Constitutional Amendment relating to Panchayati Raj and got it passed in the Parliament in December 1992. The $73^{\text {rd }}$ Constitutional Amendment Act, 1992 became a landmark step to revitalize the Indian Panchayati Raj institutions and to make them a fullfledged constitutional body. It drastically amended the provisions of Article 243 of the Constitution and inserted a new part (part-IX) and a new schedule (schedule XI) into the Constitution.

\section{History Of Panchayati Raj In Arunachal Pradesh:}

\section{Ering Committee Recommendation}

In May 1964, Governor of Assam appointed a four member committee as a preliminary step towards the direction of establishing Panchayat Raj and to consider the expansion and development of modern local self government in Arunachal Pradesh, the then NEFA. This committee came to be known as the 'Ering Committee' named after the chairman Daying Ering, the then Parliamentary Secretary in the ministry of External Affairs, New Delhi. The other members of the committee were: B.D. Pandey, the then Additional Secretary to the ministry of Finance, Brigadier D.M. Sen, former Legal Advisor and L.B. Thanga, the then Development Commissioner of NEFA. The committee was to take in consideration the scope and pattern of the authority and function exercised by the existing indigenous tribal institutions at the village level and above and to examine how can it be modified at its best or could be enlarged to introduce democratic working in the fields of judiciary, local administration and development.The committee was asked to make recommendations and give due consideration to the stage of development and advancement in respect of each tribe and the special conditions of the tribe. The committee recommended the formation of local bodies at four different levels to achieve the objective of the democratic decentralization. The bodies were to be at village, circle, district and Agency level. While, the bodies of the first three levels were on the pattern of all India level of Panchayat Raj system based on Balwant Rai Committee Report and the body at Agency level was to be of advisory in nature and was expected to discuss in detail the five year plan for NEFA and its budget and tax proposals. Though the Committee did not use the term 'Panchayat Raj' but the local bodies in the first levels were named in all India names with the Gram Panchayat, the Anchal Samiti and the Zilla Parishad in order to promote a sense of greater integration among the frontier tribe.

\section{NEFA Panchayat Raj Regulation, 1967:}

The NEFA Panchayat Raj Regulation, 1967 was promulgated by the President of India and came into force on $2^{\text {nd }}$ October, 1969. The Regulation provides for the constitution of the Gram Panchayat at village level, Anchal Samities at circle level, Zilla Parishad at district level and an Agency Council at the territorial level. The Regulation has been amended six times subsequently in the year 1970, 1971, 1972, 1980 and 1992. However, except for the amendment of 1971 , other amendments brought minor changes. Structurally, the Panchayat system provided by the Regulation was similar to those prevalent in the other parts of the country but it had different aims and objectives. Generally, the main objective of the Panchayat system in the rest of the country has been the decentralization of power but in Arunachal Pradesh it sought to bring about a uniform political practice throughout the territory in order to integrate the isolated area with the mainstream national life.

The Arunachal Pradesh Panchayat Raj Act, 1997: The passage of 73rd Constitutional Amendment created a unique situation in Arunachal Pradesh. The state government issued an Ordinance (The Arunachal Pradesh Panchayat Raj 
Ordinance 194) to replace the NEFA Panchayat Raj Regulation, 1967 in order to meet the requirements of $73^{\text {rd }}$ Constitutional Amendment Act. Accordingly, it made provisions for reservation of women, State Election, Finance Commission and five year term in conformity with the Act. The Ordinance accommodated all the main provisions of the Act but it did not make provision for the establishment of Gram Sabhas at the bottom level. In September 1994, the Ordinance was sought to be replaced by the Arunachal Pradesh Legislative Assembly. However, the Governor reserved the bill for the assent of the President. The President of India did not assent the bill and remitted it back to the Legislative Assembly with the observation that it did not have provision of Gram Sabha and does not provide for the reservation for scheduled castes. The bill was modified as Arunachal Pradesh Panchayati Raj Bill 1997 including a new chapter providing for Gram Sabhas but it did not make provision for reservation of scheduled caste population maintaining it as negligible and flouting population concentrated only in urban areas and passed the bill on March 1997.

With the introduction of PRIs, the old and traditional tribal structure is gradually giving way to more democratic, modern, flexible and heterogeneous social and political structure and in a way keeping up with the current trend of the mainstream India. The concept of leadership, power, rural development, education, women empowerment and political participation has penetrated in the minds of general populace in the state. Today, it serves as a training ground for tribal rural people especially the women folk with both the knowledge and experience about the democratic system of governance enabling them to play more important role in state and national level political foray.

\section{Review Of Literature}

Sanjay Dubey's work on "Dynamics of Tribal Local Polity and Panchayati Raj in Arunachal Pradesh" (1991) is a study on the existing village council of Arunachal Pradesh. An attempt has been made in the book to study the impact of Panchayati raj institution on the tribal societies and the socio-political changes of various tribes of the state. There is no discussion on the participation and political decision-making of the tribal women.

Tai Nyori's study "History and Culture of Adi's" (1993) gives a descriptive analysis of the history and culture of almost all the sub-tribes of Adi. The book also discusses about the village councils of the Adi tribe. He writes that there is no restriction on the participation of women in traditional village council of Kebang. But women usually do not take part in it.

Subhasini Mahapatra's study on "Women Welfare: Issues and Challenges" (2006) highlights the fact that the women welfare is a vital issue for which there is a need for total transformation of the society. The study gives a vivid portrayal of women welfare measures encompassing all vital issues and challenges as women's welfare through government plans and programmes. It also discusses about the changing scenario of tribal women in India.

Sailen D Das on "Women Empowerment and Grassroots Political Institutions" (2014) focused the need of women empowerment through the institutional mechanism which is established by the State. It brings forth a discourse on women empowerment from a theoretical contour and submerges into the field of political activism at the grassroots level which is empowerment injected for women.

\section{Objective OfThe Study}

1. To investigate the level of awareness of rights and responsibilities among the women representative in PRIs.

2. To study whether the PRIs have implemented any employment programmes for the empowerment of women.
3 . To investigate the impacts of women reservation policy in empowering women

\section{Hypotheses}

1. The decentralization of political power and reservation of women in PRIs leads to women empowerment.

2. Conducive external environment that provides opportunities, mobility, power in decision-making and access to information and resources gives more scope for women representation in PRIs.

\section{Methodology}

The study is based on stratified random sample method and the respondents are selected from the list of elected women representatives of all the three levels of the PRIs. The majority of primary data were collected via interview-schedule and the secondary data's from the Offices of State Election Commission, Office of Panchayat and Rural Development etc. Other relevant data's were collected from books, journals, reports, newspapers and various publications. The questionnaire was structured with both open-ended and closed-ended questions. Interview schedule was employed to interview 162 elected women representatives of the district. The approach of the study is historico-analytical for the fact that the analytical approach helps in critically analysing the different aspects of study and the historical approach contributes in finding facts related to the study. Behavioural approach is also adopted to understand the behavioural pattern and attitude of the respondents.

According to 2011 Census report, East Siang district has total population of 99,214 persons out of which 50,116 are male and 49,098 are female. The literacy rate is 72.54 percent. The sex ratio of the district is 980 females per one thousand male. And the work participation rate is 40.4 percent. It has six CD blocks with 15 Circles and 151 villages; the research population of the study is composed of present 162 women representatives that include- 3 Zilla Parishad Member, 23 Anchal Samiti Member and 136 Gram Panchayat Member. The data's are analyzed through a number of socio-economic and political variables such as- age, educational qualification, marital status, occupation, family size, religion, social and organizational involvement, political experience, motivational sources, knowledge on PRIs, knowledge on women reservation and sources of influence on their decision-making.

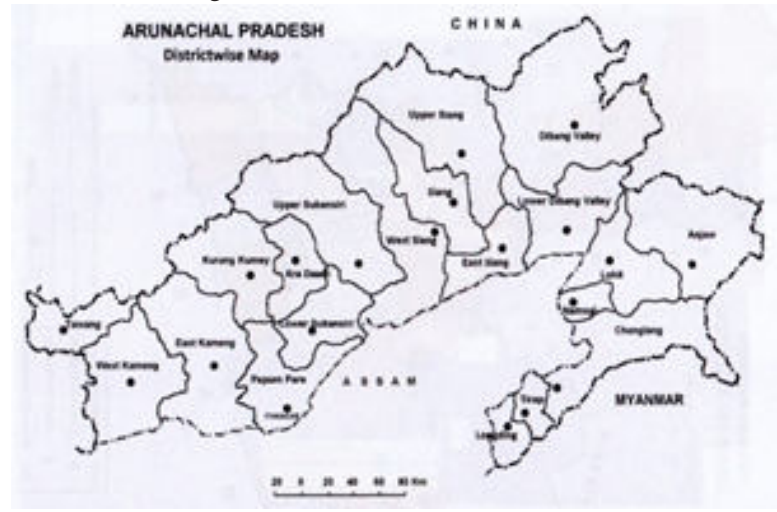

District Map Of East Siang

Table 1.1 Age-wise Distribution Of Respondents

\begin{tabular}{|l|l|l|}
\hline Age group & number & percentage \\
\hline Young (21-34) & 32 & 19.75 \\
\hline Middle aged (35-49) & 108 & 66.67 \\
\hline Aged (50 and above) & 22 & 13.58 \\
\hline Total & 162 & 100.00 \\
\hline
\end{tabular}

\section{Source: FieldWork}

An analysis of the age distribution presented in Table 1.1 
shows that the majority of elected women representatives from all the three-tiers mostly belong to middle age group of 35-49 years. It shows that women of these age groups are matured enough with more life experiences and are able to take decisions judiciously. It also proves that marriage and motherhood do not restrain them from seeking political career.

Table 1.2 Educational Background Of Respondents
\begin{tabular}{|l|l|l|}
\hline Educational Level & Number & Percentage \\
\hline Illiterate & 12 & 17.29 \\
\hline Elementary & 91 & 56.17 \\
\hline Secondary & 38 & 23.45 \\
\hline Higher & 05 & 3.09 \\
\hline total & 162 & 100.00 \\
\hline
\end{tabular}

Source: field work

The table shows that women formally educated till elementary and secondary level of education have greater representation in the Panchayat body. There are also illiterate women in this level. It is observed that few elected women with higher educational degrees belong to well to do families. It appears that grass-root elections are mostly confined to less educated women and well-educated are far less interested in the process and they are out of the election fray.

\section{Table 1.3 Marital Status Of Respondents}

\begin{tabular}{|l|l|l|}
\hline Marital status & number & percentage \\
\hline Married & 162 & 100 \\
\hline Unmarried & 00 & 0 \\
\hline total & 162 & 100.00 \\
\hline
\end{tabular}

\section{Source: field work}

The table shows that all the elected women respondents are married. This shows that their family supports them for political activities. The absence of unmarried women in the election fray indicates that younger or unmarried women may be busy in making their career or providing helping hand to their mothers in daily household chores.

Table 1.4 Religion-wise Classification Of Respondents

\begin{tabular}{|l|l|l|}
\hline Religion & number & percentage \\
\hline Buddhism & 00 & 00 \\
\hline Christianity & 58 & 35.80 \\
\hline Donyi-Poloism & 100 & 61.73 \\
\hline Hindu & 02 & 1.23 \\
\hline Others & 02 & 1.23 \\
\hline Total & 162 & 100.00 \\
\hline
\end{tabular}

Source: field work

The table shows that the women following Donyi Poloism which is an indigenous tribal religion in the state have better representation in PRIs followed by Christians.

Table 1.5 Occupational Background Of Respondents

\begin{tabular}{|l|l|l|}
\hline Occupation & number & percentage \\
\hline Household & 02 & 1.23 \\
\hline Cultivation & 142 & 87.65 \\
\hline Business & 18 & 11.11 \\
\hline Others & 00 & 00 \\
\hline total & 162 & 100.00 \\
\hline
\end{tabular}

\section{Source:field work}

The table shows that majority of women are involved in cultivation of their fields. Few were found in small businesses like selling clothes, kitchen articles, handicrafts etc. It is observed that tribal women work hard along with their spouses to raise income.

\section{Table 1.6 Political Experience Of Respondents}

\begin{tabular}{|l|l|l|}
\hline Political experience & number & percentage \\
\hline Yes & 21 & 12.97 \\
\hline No & 141 & 87.03 \\
\hline total & 162 & 100.00 \\
\hline
\end{tabular}

Source:field work

It is observed that majority of the elected members are first entrants and hence are less experienced.

Table 1.7 Party Affiliation Of Respondents

\begin{tabular}{|l|l|l|}
\hline Political Party & number & percentage \\
\hline INC & 65 & 40.12 \\
\hline BJP & 76 & 46.91 \\
\hline NCP & 2 & 1.23 \\
\hline IND & 3 & 1.86 \\
\hline Others & 16 & 9.88 \\
\hline total & 162 & 100.00 \\
\hline
\end{tabular}

Source: field work

Like the Assembly elections and national level politics, elections of PRIs are also fought on the party line and indicate increasing party influence in the functioning of the Panchayat.

Table 1.8 Distribution Of Respondents On Motivational Sources

\begin{tabular}{|l|l|l|}
\hline Sources & number & percentage \\
\hline Political ambition & 82 & 50.62 \\
\hline Family & 45 & 27.78 \\
\hline Public demand & 11 & 6.79 \\
\hline Political party & 21 & 12.96 \\
\hline Women reservation & 3 & 1.86 \\
\hline total & 162 & 100.00 \\
\hline
\end{tabular}

Source:field work

The majority of the respondent's main source of encouragement to contest election came from their own political ambition, while some from their family. It also appears that some respondents had been influenced by the factors such as demand of public for leadership, women reservation system and even due to call from certain political parties. It is noted that those women leaders who cited a call from political parties to contest election, had been exposed to political influence either through their own political experience or through their husbands influence being a part of local party politics. It is also significant to understand that gaining political support from certain political party is not always possible for many women political aspirants. This mainly restricts many from participating.

Table 1.9 Social And Organizational Involvement Of Respondents

\begin{tabular}{|l|l|l|}
\hline Category & number & percentage \\
\hline Socio-cultural Organization & 10 & 6.17 \\
\hline Self-Help Groups & 129 & 79.63 \\
\hline Non Governmental Organizations & 6 & 3.70 \\
\hline Others & 1 & 10.50 \\
\hline total & 162 & 100.00 \\
\hline
\end{tabular}

Source: field work

The table shows that majority of respondents are involved in self employment generating micro-economic organizations, i.e. Self Help Groups (SHGs) and the 'Others' mentioned in the table represents those who have no involvement in any sociocultural or Non-Governmental Organizations other than being a Panchayat leader. 
Table 1.10 Respondents Level Of Knowledge On The $73^{\text {rd }}$ Amendment Act

\begin{tabular}{|l|l|l|}
\hline Response & number & percentage \\
\hline Know & 65 & 41.36 \\
\hline Partially know & 30 & 18.52 \\
\hline Don't know & 67 & 40.12 \\
\hline total & 162 & 100.00 \\
\hline
\end{tabular}

Source:field work

It is observed that majority of respondents know about the provision of women reservation in the Act. This proves that awareness level is quite good.

Table 1.11 Respondents Knowledge On Rural Developmental Programmes

\begin{tabular}{|l|l|l|l|l|}
\hline Response & $\begin{array}{l}\text { Before } \\
\text { training }\end{array}$ & percentage & $\begin{array}{l}\text { After } \\
\text { training }\end{array}$ & percentage \\
\hline Know & 28 & 17.28 & 158 & 97.53 \\
\hline Don't know & 100 & 61.73 & 00 & 00 \\
\hline Partially know & 34 & 20.99 & 04 & 2.47 \\
\hline total & 162 & 100.00 & 162 & 100.00 \\
\hline
\end{tabular}

Source: field work

It is observed that after attending training and orientation programmes, majority of the respondents are now aware of the rural developmental programmes initiated by the government, which is crucial for rural development.

Table 1.12 Participation In Panchayat Meetings, Discussions And Decision-making

\begin{tabular}{|l|l|l|}
\hline Frequency & number & percentage \\
\hline Whenever held & 156 & 96.30 \\
\hline Sometimes & 06 & 37.00 \\
\hline Seldom & 00 & 00 \\
\hline total & 162 & 100.00 \\
\hline
\end{tabular}

Source: field work

The table reveals that majority of the respondents participate in Panchayat meetings and participate in discussions.

Table 1.13 Enhancement Of Familial, Economic And Social Status OfThe Respondents

\begin{tabular}{|l|l|l|}
\hline \multicolumn{2}{l|}{$\begin{array}{l}\text { Responses of the Elected Women } \\
\text { Respondents }\end{array}$} & percentage \\
\hline Enhanced Economic Status & 02 & 1.24 \\
\hline Enhanced Social status & 160 & 98.76 \\
\hline Both of the above & 00 & 00 \\
\hline Total & 162 & 100.00 \\
\hline
\end{tabular}

Source: field work

It is observed that majority of the respondents are of the view that their social status has been enhanced and two among them even accepted that it has enhanced their economic status too.

\section{SUMMMARY AND CONCLUSION}

The following conclusion can be drawn in the light of the objective of the study on the basis of empirical analysis:

1. In all the three tiers of Panchayat, middle aged women have higher representation, which indicates that marriage and motherhood does not restrain them from their political ambition. Also there is a surge of entry of fairly young aged women.

2. It is observed that majority are with elementary education followed by women with secondary level education. Hence, the low level of education proves hindrance in the way achieving the goal of local self governance.

3. It is also observed that women with higher education are less interested in grass-roots politics.

4. Study shows that majority of women are from joint family and married. This signifies that they are able to balance both their family and political life. They also have full family support.

5. It is also found that social status of the family have a strong influence in determining the political career of the women representative.

6. The study reveals that members following the indigenous tribal religion have higher representation and that traditional customary and cultural norm does not restrict them from entering into politics.

7. It is observed that majority of the respondents are from agricultural background and hard working women cultivating their fields and working hand in hand with their spouses to earn income for their family.

8. It is found that majority of the respondents are first timers in politics and hence less experienced and hence proves hindrance in the working of Panchayat.

9. Panchayat office becomes the first learning institute of leadership for the newly elected women representatives.

10. PRI elections have high influence of political parties. And in times proves detrimental for the proper functioning of rural development based on party lines.

11. It is significant to understand that gaining political support from certain political party is not always possible for many women aspirant and it restricts them from participating in PRI election.

12. Women reservation policy played a major role in convincing a sizeable amount of women to participate in PRI elections.

13. It is noted that respondents have limited exposure to greater public involvement and thus, it has negative impact on the working in PRIs.

14. The study proves that women representatives require more awareness and knowledge for the better functioning of the PRIs.

15. It is imperative for the elected representatives to know about various schemes of rural development programmes initiated by the government and how to implement it.

16. It is observed that few women leaders refrain themselves from expressing their views. Few of them accepted that sometimes their husbands or sons attend the meeting for them and even expresses their opinions on behalf of her in meetings. It proves that some elected women are still not confident enough to raise their voice and express.

17. The data also proves that women leaders are gradually gaining self-confidence and their status in society are being enhanced.

18. There is also an indication that women leaders are being accepted as a part of grass-root political process. Their political and societal exposure is enhancing the status of their family too.

19. Majority of women are interested to continue in politics.

20. Male dominance is still prevalent in all the levels of PRIs.

21.PRI elections are treated as pre-Assembly election tests for the political parties. Hence, they try and make every effort to win. This has increased the importance of Panchayat election with involvement of almost all the political parties in the state.

\section{SUGGESTION}

1. The mere reservation will not solve the problem unless the women representatives are duly empowered to function effectively in decision-making process. Some admitted that orientation courses can acquaint them with their role and power. It was also revealed that few women were not willing to contest but their husbands, friends and family members took initiative in inducting them to the election fray. Hence, a push is necessary to boost their self-confidence and political awareness trainings and orientation programmes from time to time is must.

2. It was also found in many cases that women members were kept aloof from financial expenses of Panchayat by the superior male members and hence it needs to be more transparent.

3. The myth that tribal women are politically and socially 
passive and cannot perform political roles effectively has been largely disapproved by the entry of considerable number of women into the PRIs especially after the implementation of $73^{\text {rd }}$ Constitutional Amendment Act, 1992 and hence proved that the women in the East Siang have shown political activism by participating and representing in the political decision-making and are performing their assigned duties effectively.

4. For the empowerment of the women representatives, it is imperative to create a multi-dimensional effort from all the concerned policy makers, governments, training institutions, NGOs, men and by the women themselves.

\section{REFERENCES}

1. Lourdes, G.Rita Goretti, (2015)Women Empowerment New Delhi.

2. Ram, D. Sundar, (2010) Grassroots Planning and Local Governance in India: Policy Initiatives and Peoples Participation"New Delhi.

3. Marilee, Karl, (1995) Women and Empowerment: Participation and Decisionmaking, London.

4. Nyori, Tai, (1993) History and Culture of the Adis, , Omsons Publication, New Delhi.

5. District Census handbook of East Siang (2011) Directorate of Census Operations, Government of Arunachal Pradesh, Pasighat.

6. Statistical Abstract of Arunachal Pradesh (2015) Directorate of Economics and Statistics, Government of Arunachal Pradesh.

7. Office of District Election Officer,(2013) Government of Arunachal Pradesh.

8. Das, Sailen D, (2014) Women Empowerment and Grassroots Political Institutions: An empirical Study, Guwahati.

9. Census (2011) Status of Literacy. Government of India. Available at: http://censusindia.gov.in/2011-provresults/data files/mp/07Literacy.pdf.

10. Almond, Gabriel. A and Verba, Sidney, (1963) the Civic Culture: Political Attitudes and Democracy in Five Nations. Beverly Hills: Sage Publication.

11. Verba, Sidney, Norman H, and Jae-on Kim. (1971) The Modes of Participation: A cross-national Comparision, Beverly Hills: Sage Publication, p-10. 